\title{
Pemberian Scaffolding untuk Memperbaiki Proses Berpikir Komputasional Siswa dalam Memecahkan Masalah Matematika
}

\author{
M. Gunawan Supiarmo ${ }^{1}$, Liny Mardhiyatirrahmah ${ }^{2}$ Turmudi $^{3}$ \\ 1, 2 Program Magister Pendidikan Matematika, Fakultas Tarbiyah dan Ilmu Keguruan, UIN Maulana Malik Ibrahim, Jl. \\ Gajayana No.50, Malang, Indonesia \\ ${ }^{3}$ Program Studi Matematika, Fakultas Sains dan Teknologi, UIN Maulana Malik Ibrahim, Jl. Gajayana No.50, Malang, \\ Indonesia \\ gunawansupiarmo@gmail.com
}

\begin{abstract}
Computational thinking is defined as the process of solving problems using logic gradually and systematically. This thinking ability is needed to help and facilitate students in solving math problems. However, the facts in the field show that students have not been able to use abstractions for given mathematical problems and perform algorithms. This study aims to describe the students' computational thinking process in solving mathematics problems through scaffolding using HOTS questions in the PISA model of linear programming material for class XI at MA Daruttauhid Malang. This type of research is a descriptive study with a qualitative approach. The research data consisted of students' answers, think aloud, and semi-structured interview results. The results showed that scaffolding can help and improve the computational thinking process because giving questions, instructions, reminders, directions, or encouragement makes students' computational thinking optimally active. This is evidenced by the computational thinking stage of students who previously were only able to achieve pattern recognition, becoming students who can reach the abstraction stage and algorithmic thinking in solving mathematical problems.
\end{abstract}

Keywords: Computational Thinking, Scaffolding, Problem Solving.

\begin{abstract}
Abstrak
Berpikir komputasional didefinisikan sebagai proses pemecahan masalah menggunakan logika secara bertahap dan sistematis. Kemampuan berpikir ini sangat dibutuhkan untuk membantu dan memudahkan siswa dalam memecahkan masalah matematika. Namun, fakta di lapangan menunjukkan bahwa siswa belum mampu menggunakan abstraksi terhadap masalah matematika yang diberikan serta melakukan algoritma. Penelitian ini bertujuan mendeskripsikan proses berpikir komputasional siswa pada pemecahan masalah matematika melalui scaffolding menggunakan soal HOTS model PISA materi program linear kelas XI di MA Daruttauhid Malang. Jenis penelitian ini adalah penelitian deskriptif dengan pendekatan kualitatif. Adapun data penelitian terdiri atas jawaban siswa, think aloud, dan hasil wawancara semiterstruktur. Hasil penelitian menunjukkan bahwa scaffolding dapat membantu dan memperbaiki proses berpikir komputasional karena pemberian pertanyaan, petunjuk, pengingat, arahan, atau dorongan membuat berpikir komputasional siswa menjadi aktif secara optimal. Hal ini dibuktikan dari tahapan berpikir komputasional siswa yang sebelumnya hanya mampu mencapai pengenalan pola, menjadi siswa yang dapat mencapai tahap abstraksi dan berpikir algoritma dalam memecahkan masalah masalah matematika.
\end{abstract}

Kata kunci: Berpikir Komputasional, Scaffolding, Pemecahan Masalah.

Copyright (c) 2021 M. Gunawan Supiarmo, Liny Mardhiyatirrahmah, Turmudi

$\triangle$ Corresponding author: M. Gunawan Supiarmo

Email Address: gunawansupiarmo@gmail.com (Jl. Gajayana No.50, Malang, Indonesia)

Received 12 Februari 2021, Accepted 08 Maret 2021, Published 08 Maret 2021

\section{PENDAHULUAN}

Berpikir komputasional pertama kali diperkenalkan oleh Seymour Papert pada tahun 1980 (Angeli \& Giannakos, 2020). Beberapa negara maju seperti Inggris, Australia, Polandia dan Korea Selatan telah memperkenalkan pemikiran komputasional mulai dari pendidikan Sekolah Dasar dan Sekolah Menengah Pertama (Città dkk., 2019). Kebijakan ini dilandasi kesulitan guru untuk memperbarui metode pengajaran monoton yang biasa digunakan selama bertahun-tahun (Nuraisa 
dkk., 2019; Wing, 2014).

Berpikir komputasional didefinisikan sebagai proses pemecahan masalah menggunakan logika secara bertahap dan sistematis (Wing, 2014). Berpikir komputasional menjadi salah satu teknik pemecahan masalah yang tidak hanya penting dalam proses pemrograman komputer saja, tetapi dibutuhkan siswa pada berbagai disiplin ilmu tidak terkecuali pada bidang matematika (Lee dkk., 2014).

Berpikir komputasional sangat dibutuhkan untuk membantu dan memudahkan siswa dalam memecahkan masalah matematika karena melibatkan berbagai keahlian dan teknik yang melatih siswa merumuskan masalah dengan menjabarkan masalah tersebut menjadi bagian-bagian yang kecil yang mudah dipecahkan (Lee dkk., 2014). Selain itu, melalui berpikir komputasional juga dapat merangsang siswa berpikir kreatif dalam meyelesaikan permasalahan (Angeli \& Giannakos, 2020; Wing, 2014).

Faktanya, pendekatan pembelajaran saat ini membatasi siswa mengembangkan proses berpikir komputasional (Marcelino dkk., 2018). Guru sering kali menggunakan metode pengajaran monoton, sehingga siswa kurang tertarik untuk belajar (Tedre \& Denning, 2016). Guru terbiasa memecahkan masalah matematika menggunakan rumus, kemudian siswa menyalin formula tersebut untuk dihafal dan digunakan menemukan jawaban benar ketika ujian (Lee dkk., 2014; Selby, 2013). Tentunya metode tersebut membuat siswa kurang tertarik dan aktif dalam mengembangkan kemampuan berpikir komputasional, sehingga berdampak terhadap kemampuan berpikir komputasional siswa menjadi rendah (Tedre \& Denning, 2016).

Berdasarkan pra-penelitian yang dilakukan di kelas XI MA Daruttauhid Malang melalui pemberian tes awal menunjukkan bahwa siswa masih mengaplikasikan prosedur umum seperti menggunakan contoh, substitusi dan eliminasi dalam memecahkan masalah program linear. Adapun tahapan berpikir komputasional yang dilakukan oleh siswa hanya sampai pada tahap dekomposisi dan pengenalan pola saja. Tak hanya itu, siswa juga belum mampu menggunakan abstraksi terhadap masalah matematika yang diberikan. Keterampilan berpikir algoritma siswa juga belum terlihat karena terdapat tahapan-tahapan pemecahan masalah yang dilakukan siswa secara tidak logis dan sistematis. Oleh karena itu, dapat disimpulkan bahwa kemampuan berpikir komputasional siswa masih rendah.

Rendahnya kemampuan berpikir komputasional siswa sesuai dengan hasil kajian literatur yang dilakukan oleh peneliti-peneliti sebelumnya. Penelitian-penelitian terdahulu menunjukkan bahwa ratarata kemampuan berpikir komputasional siswa masih berada di kategori rendah karena siswa hanya mampu mencapai tahapan pengenalan pola dan prosedur yang diaplikasikan kurang koheren. Hal ini disebabkan siswa belum memunculkan keterampilan abstraksi dan berpikir algoritma dalam memecahkan masalah matematika. Adapun siswa yang memiliki kemampuan berpikir komputasional kategori tinggi, yaitu siswa yang dapat mencapai tahapan abstraksi dan berpikir algoritma masih sangat sulit ditemukan (Afitra Ilham Rodhan Syah, 2020; Ayub dkk., 2017; Brackmann dkk., 2017; Harsa Wara Prabawa, 2019; Tedre \& Denning, 2016). 
Berdasarkan masalah tersebut, siswa perlu mendapatkan treatment yang dapat menstimulasi proses berpikir komputasional siswa dari yang hanya mampu melakukan dekomposisi dan pengenalan pola, menjadi siswa yang dapat mencapai tahap abstraksi dan berpikir algoritma. Beberapa penelitian terdahulu telah mengaplikasikan beragam treatment untuk memperbaiki tahapan berpikir komputasional siswa, antara lain menggunakan tantangan bebras task (Ayub dkk., 2017), melakukan pengembangan dan penerapan modul bahasa pemrogaman scratch (Afitra Ilham Rodhan Syah, 2020), menerapkan model quantum teaching and learning dalam multimedia pembelajaran interaktif (Harsa Wara Prabawa, 2019), melalui latihan pemrograman komputer, dan dengan aktivitas unplugged yang tidak memerlukan penggunaan perangkat digital atau jenis perangkat keras tertentu (Brackmann dkk., 2017). Empat treatment berbeda yang telah dilakukan untuk melengkapi tahapan berpikir komputasional siswa. Adapun pada penelitian ini, treatment yang digunakan memperbaiki langkahlangkah berpikir komputasional siswa adalah melalui scaffolding.

Scaffolding adalah upaya memberikan bantuan kepada siswa untuk mengatasi hambatan dalam memecahkan masalah matematika (Fatimah dkk., 2019; Maharani \& Subanji, 2018). Adapun bantuan tersebut berupa pertanyaan, petunjuk, pengingat, arahan, atau dorongan yang diberikan kepada siswa saat melakukan kesalahan dalam menemukan solusi penyelesaian terhadap masalah yang ditemukan (Maharani \& Subanji, 2018). Selain itu, scaffolding dapat membantu siswa dalam mengembangkan keterampilan berpikirnya dengan baik dalam pemecahan masalah matematika (Sunaryo \& Fatimah, 2019).

Penggunaan scaffolding dalam penelitian ini bertujuan untuk memperbaiki proses berpikir komputasional siswa. Scaffolding dilakukan dengan memberikan pertanyaan, petunjuk, pengingat, arahan, atau dorongan yang menstimulus siswa untuk memeriksa kembali langkah-langkah pemecahan masalah yang sudah dilakukan sehingga siswa dapat memperbaiki dan melengkapi tahapan berpikir komputasional tersebut secara optimal. Hal ini juga ditunjang dengan belum ditemukannya penelitian terkait pemberian scaffolding untuk melengkapi tahapan berpikir komputasional siswa dari yang hanya mampu mencapai dekomposisi dan pengenalan pola, menjadi siswa yang dapat mencapai tahap abstraksi dan berpikir algoritma dalam memecahkan masalah matematika. Oleh sebab itu, peneliti akan melakukan penelitian yang berjudul "Pemberian Scaffolding untuk Memperbaiki Proses Berpikir Komputasional Siswa dalam Memecahkan Masalah Matematika".

\section{METODE}

Jenis penelitian ini adalah penelitian deskriptif dengan pendekatan kualitatif. Adapun subjek penelitian sebanyak 2 siswa dari 49 siswa kelas XI MA Daruttauhid Malang. Pemilihan subjek dilakukan dengan teknik purposive sampling yaitu siswa yang memiliki kemampuan berpikir komputasional rendah dan mempunyai kemampuan komunikasi yang lancar berdasarkan hasil tes. Teknik pengumpulan data dilakukan melalui tes, think aloud, dan wawancara semi terstruktur. 
Wawancara semi terstruktur digunakan untuk membantu siswa dalam melakukan think aloud ketika peneliti ingin mendalami dan mengklarifikasi proses berpikir komputasional siswa yang belum jelas dari jawaban siswa. Adapun roadmap pada penelitian ini dapat dilihat pada diagram berikut.

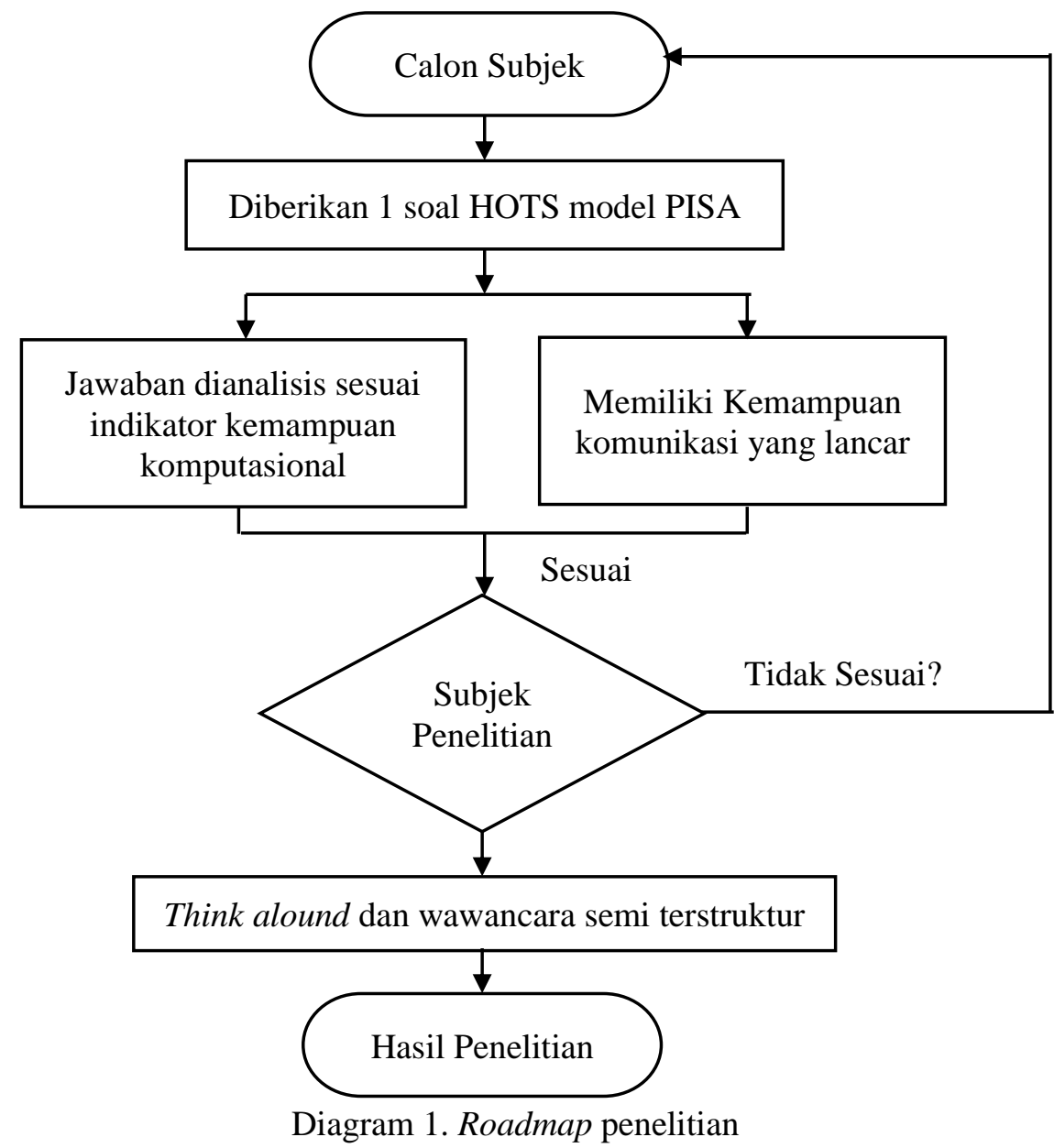

Berdasarkan roadmap di atas, seluruh siswa diberikan 1 soal HOTS model PISA yang dikembangkan oleh tim Pendidikan Matematika Realistik Indonesia atau PMRI (2011). Meskipun telah dikembangkan oleh tim khusus, keabsahan data kembali dilakukan dengan perpanjangan keikutsertaan, ketekunan pengamatan, triangulasi, pengecekan anggota, uraian rinci, dan pengecekan sejawat. Peneliti ikut tergabung dalam proses dan aktivitas terkait dengan mengamati, memahami bahkan berada di lingkungan yang sama dengan subjek yang diteliti dalam rangka pengumpulan data. Tak hanya itu, peneliti juga melakukan pengamatan dengan terjun langsung di lokasi pengumpulan data guna melihat bagaimana kondisi eksternal dan internal subjek. Berikut ini soal yang diberikan kepada siswa untuk mengambil data penelitian.

Pabrik kue menyediakan dua jenis kue berbentuk cakram dengan ketebalan sama, tetapi ukuran beda. Permukaan kue yang kecil dan besar masing-masing berdiameter $10 \mathrm{~cm}$ dan $15 \mathrm{~cm}$. 


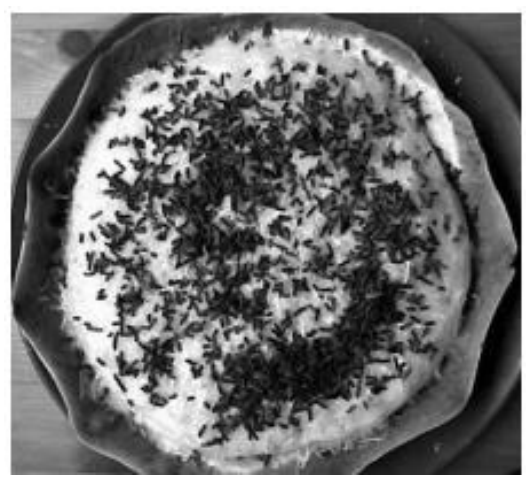

Gambar 1. Kue

Jika setiap kue yang kecil dan besar dijual masing-masing dengan harga Rp10.000,00 dan Rp15.000,00, manakah yang lebih menguntungkan, membeli tiga kue yang kecil atau dua kue yang besar? Tuliskan alasan Anda.

Selanjutnya jawaban siswa siswa dilihat berdasarkan indikator proses berpikir komputasional (Lee, 2014), antara lain dekomposisi, pengenalan pola, abstraksi, dan berpikir algoritma. Kemudian peneliti mengambil 2 subjek penelitian, antara lain 1 kategori subjek berpikir komputasional rendah pertama (SBKR 1), dan 1 kategori subjek berpikir komputasional rendah kedua (SBKR 2). Kategori SBKR 1 yaitu subjek yang mampu mencapai tahap pengenalan pola tanpa melakukan dekomposisi terlebih dahulu, sedangkan SBKR 2 adalah subjek yang dapat melakukan dekomposisi dan pengenalan pola.

Subjek penelitian kemudian diwawancarai untuk memperjelas hasil pekerjaan subjek dalam memecahkan masalah matematika. Ketika proses wawancara, subjek diminta menyampaikan proses berpikirnya (think aloud) dalam memecahkan masalah matematika, sehingga diketahui kekurangan proses berpikir komputasional siswa yang kemudian menjadi pedoman peneliti untuk melakukan scaffolding. Adapun teknik analisis data pada penelitian ini dilakukan melalui tahap antara lain reduksi data, penyajian data, dan penarikan kesimpulan atau verifikasi. Selain itu, verifikasi data juga dilakukan melalui triangulasi dengan melakukan wawancara terhadap subjek.

\section{HASIL DAN DISKUSI}

\section{Proses Berpikir Komputasional S1 pada Pemecahan Masalah Matematika}

1. Proses Berpikir Komputasional S1 pada Pemecahan Masalah Matematika Sebelum Scaffolding

S1 merupakan Kategori SBKR 1 yaitu subjek yang mampu mencapai tahap pengenalan pola tanpa melakukan dekomposisi. Berikut disajikan jawaban dan hasil wawancara terkait proses berpikir komputasional pada pemecahan masalah matematika yang dilakukan S1. 


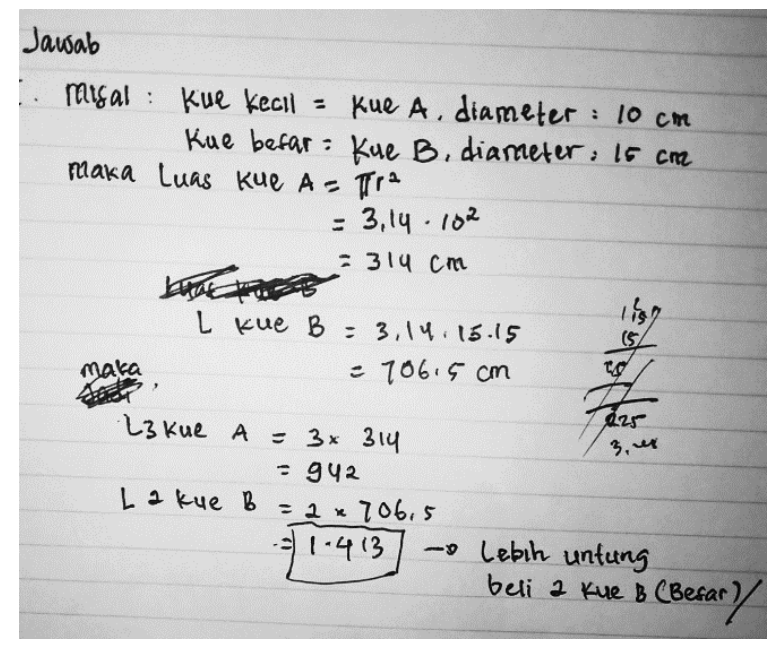

Gambar 2. Jawaban S1

Data proses berpikir komputasional S1 dapat dilihat pada kutipan wawancara berikut ini.

Wawancara [1]

P : "Coba adik jelaskan bagaimana langkah-langkah adik menemukan jawaban terhadap masalah ini?"

S1: "Nggih kak, jadi saya melakukan pemisalan kalau kue kecil adalah A dan kue besar itu B. Kemudian saya mencari luas permukaan kedua kuenya. Lalu saya pakai rumus luas lingkaran kak, yaitu mmm $\pi r^{2}$. Nah baru kemudian saya menghitung luas kue kecil adalah $3,14 \times 10^{2}=314$ $\mathrm{cm}$. Trus saya hitung luas kue besar itu jadinya $3,14 \times 15^{2}=706,5 \mathrm{~cm}$. Selanjutnya saya menghitung luas dari 3 kue kecil yaitu $942 \mathrm{~cm}$ dan luas kue besar $1.413 \mathrm{~cm}$. Jadi lebih untung itu kalau membeli 2 kue besar."

P : “Apa yang kamu pahami dari masalah ini?"

S1: "Kan kita diminta menghitung mana yang lebih meguntungkan membeli 2 kue besar atau 3 kue kecil kak."

P : "Lalu bagaimana strategi yang adik gunakan untuk menjawab masalah ini?"

S1: "Saya pakai luas lingkaran kak karena bentuk cakram itu lingkaran jadi $\pi \mathrm{r}^{2}$."

Berdasarkan jawaban dan hasil wawancara di atas dapat diketahui bahwa pada tahap memahami masalah, S1 tidak menguraikan informasi yang diketahui dan ditanyakan pada masalah yang diberikan. Hal ini membuktikan bahwa S1 tidak mengawali proses berpikirnya dengan melakukan dekomposisi terlebih dahulu.

Selanjutnya, pada tahap menyusun strategi S1 melakukan pemisalan, dimana S1 menemukan karateristik serupa dan menghubungkan masalah tersebut dengan materi yang sudah diperoleh sebelumnya yaitu luas lingkaran. S1 membuat pemisalan bahwa kue kecil = A dan kue besar = B . Kemudian S1 langsung menghitung luas masing-masing kue dengan formula luas lingkaran yaitu $\pi \mathrm{r}^{2}$. Hal ini membuktikan bahwa S1 melakukan pengenalan pola terhadap masalah yang diberikan.

Pada tahap melaksanakan rencana S1 melakukan kesalahan dimana saat menghitung luas permukaan kue kecil dan kue besar S1 tidak terlebih dahulu mencari jari-jari kedua kue tersebut. 
Terlihat pada proses perhitungan yang dilakukan, S1 melakukan substitusi terhadap nilai diameter lingkaran, sehingga didapatkan hasil hitung dari 3,14 × 10 adalah $314 \mathrm{~cm}$. Selain itu, pada perhitungan luas permukaan kue besar S1 juga melakukan substitusi dengan nilai diameter sehingga diperoleh luas kue adalah 706,5 cm.

Kesalahan yang dilakukan S1 dalam menghitung luas permukaan kue kecil dan besar berdampak pada langkah selanjutnya. S1 menemukan luas 3 kue kecil adalah $942 \mathrm{~cm}$ dan luas 2 kue besar adalah $1.413 \mathrm{~cm}$. Adapun pada tahap menemukan solusi penyelesaian, S1 tidak membuat kesimpulan jawaban sehingga S1 dinyatakan belum mencapai indikator abstraksi pada pemecahan masalah matematika.

Berdasarkan proses pemecahan masalah yang dilakukan secara keseluruhan dapat disimpulkan bahwa S1 juga belum mencapai tahap berpikir algoritma karena terdapat langkahlangkah pemecahan masalah yang kurang lengkap seperti tidak menguraikan informasi yang diketahui dan ditanyakan, kesalahan dalam menghitung luas permukaan kedua kue, dan tidak membuat kesimpulan dari solusi penyelesaian yang ditemukan terhadap masalah tersebut.

\section{Proses Berpikir Komputasional S1 pada Pemecahan Masalah Matematika Saat Scaffolding}

Berdasarkan pencapaian berpikir komputasional yang belum lengkap diketahui bahwa S1 tidak melakukan dekomposisi, abstraksi dan berpikir algoritma, sehingga peneliti melakukan scaffolding untuk memperbaiki dan melengkapi tahapan berpikir komputasional S1 secara optimal. Berikut kutipan wawancara peneliti dengan S1 untuk memperbaiki proses berpikir komputasional S1 pada pemecahan masalah matematika melalui scaffolding.

Wawancara [2]

P : "Coba sekarang adik identifikasi apa saja informasi yang diketahui pada masalah tersebut?"

S1: "Yang diketahui itu diameter permukaan kue kecil adalah $10 \mathrm{~cm}$ harganya Rp. 10.000, sedangkan diameter permukaan kue besar $=15 \mathrm{~cm}$ dengan harga Rp. 15.000 kak."

P : "Lalu apa informasi yang ditanyakan pada masalah ini?"

S1: "Mana yang lebih menguntungkan antara membeli tiga kue kecil atau dua kue besar."

Berdasarkan kutipan wawancara [2], peneliti memberikan scaffolding berupa perintah untuk melakukan identifikasi terhadap apa yang diketahui dan ditanyakan pada masalah yang diberikan. Hal ini dilakukan untuk memunculkan keterampilan dekomposisi S1 dalam memecahkan masalah matematika. Melalui scaffolding tersebut, S1 menguraikan informasi menjadi lebih sederhana, sehingga memungkinkan untuk memudahkannya membangun penyelesaian.

Setelah kemampuan dekomposisi S1 dapat dimunculkan, peneliti kembali memberikan scaffolding berupa petunjuk, pengingat dan pertanyaan yang merangsang siswa untuk melakukan abstraksi yang dapat dilihat pada kutipan wawancara berikut.

Wawancara [3] 
Pemberian Scaffolding untuk Memperbaiki Proses Berpikir Komputasional Siswa dalam Memecahkan Masalah

P : "Oke, pada jawaban adik menghitung luas permukaan kue dengan rumus luas lingkaran. Apa alasannya?"

S1: "Ya karena luas permukaan saja kan kak, makanya saya menggunakan luas lingkaran."

P : "Iya tepat sekali, disini adik menulis luas lingkaran $=\pi r^{2}$, sekarang coba inget kembali apa itu r!"

S1: "r itu kan jari-jari lingkaran kak."

P : "Nah, kalau begitu bagaimana cara menemukan jari-jari?"

S1: "Astaga ia kak jari-jari adalah setengah dari diameter, sebelumnya saya salah berarti."

P : "Nah sekarang adik dapat memperbaiki kesalahan dalam menghitung tersebut."

S1: "Nggih kak, sebelumnya saya menghitung luas permukaan kedua kue dengan mengkuadratkan diameternya langsung (sambil memperbaiki jawaban)."

S1: "(2 menit setelah S1 melakukan perbaikan) Kalau begitu sekarang adik sudah menemukan hasil hitung yang benar, lalu apa kesimpulan yang dapat diambil dari solusi yang adik dapatkan?.'

P : "Kesimpulannya lebih menguntungkan membeli 2 kue besar ketimbang 3 kue kecil karena luas permukaan 2 kue besar itu lebih besar dari 3 kue kecil."

Berdasarkan kutipan wawancara [3], peneliti memberikan pertanyaan yang merangsang S1 untuk membuat kesimpulan terhadap solusi penyelesaian yang ditemukan. Melalui pertanyaan tersebut, terlihat S1 membuat kesimpulan bahwa pilihan yang tepat adalah dengan membeli 2 kue besar karena luas permukaannya lebih besar dari 3 kue kecil.

Selanjutnya, setelah kemampuan abstraksi S1 dapat dimunculkan, peneliti kembali memberikan scaffolding berupa pertanyaan yang merangsang siswa untuk berpikir secara algoritma yang dapat dilihat pada kutipan wawancara berikut.

Wawancara [4]

P : "Setelah kakak memberikan petunjuk dan pertanyaan kepada adik, sekarang coba dijelaskan bagaimana langkah-langkah yang dilakukan adik untuk menemukan solusi penyelesaian terhadap masalah yang diberikan?".

S1: "Awalnya kita menentukan apa yang diketahui dan ditanyakan, diketahui itu diameter permukaan kue kecil adalah $10 \mathrm{~cm}$ harganya Rp. 10.000, sedangkan diameter permukaan kue besar $=15$ cm dengan harga Rp. 15.000 kak, dan yang ditanya adalah mana yang lebih menguntungkan antara membeli tiga kue kecil atau dua kue besar. Selanjutkan melakukan pemisalan bahwa kue kecil $=\mathrm{A}$ dan kue besar $=\mathrm{B}$. Kemudian menghitung luas permukaan kedua kue melalui rumus lingkaran yaitu $\pi r^{2}$. Setelah menemukan luasnya baru kemudian menyimpulkan bahwa membeli 2 kue besar lebih untung dari pada 3 kue kecil."

Berdasarkan kutipan wawancara [4], peneliti memberikan pertanyaan yang merangsang S1 menjabarkan langkah-langkah untuk menemukan solusi penyelesaian. Melalui pertanyaan tersebut, terlihat S1 memaparkan bagaimana proses pemecahan masalah yang dilakukan dari tahap memahami masalah sampai menemukan solusi akhir. S1 menjelaskan apa yang diketahui pada masalah, apa yang ditanyakan masalah, dan bagaimana langkah-langkah untuk menemukan solusi dengan melakukan 
pemisalan, menghitung luas permukaan kedua kue, melakukan perbandingan dan diakhiri kesimpulan jawaban. Berikut jawaban siswa setelah diberikan scaffolding.

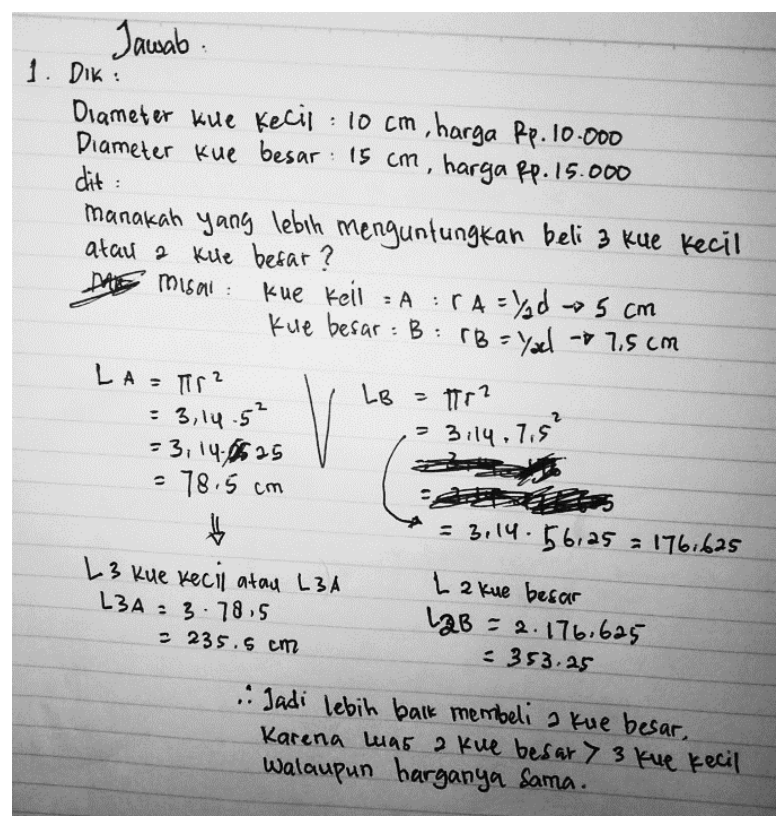

Gambar 3. Scaffolding S1

\section{Proses Berpikir Komputasional S2 pada Pemecahan Masalah Matematika}

1. Proses Berpikir Komputasional S2 pada Pemecahan Masalah Matematika Sebelum Scaffolding

S2 merupakan Kategori SBKR 2 yaitu subjek yang dapat melakukan dekomposisi dan pengenalan pola. Berikut disajikan jawaban dan hasil wawancara terkait proses berpikir komputasional pada pemecahan masalah matematika yang dilakukan S2.

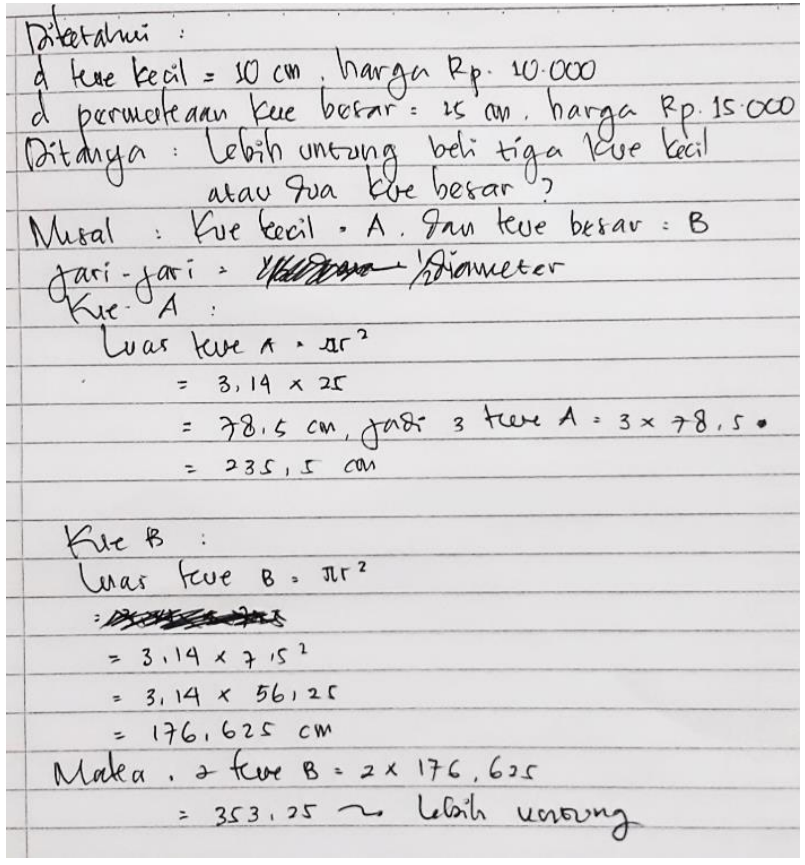

Gambar 4. Jawaban S2 
Triangulasi data mengenai proses berpikir komputasional S2 yang dapat dilihat pada kutipan wawancara berikut ini.

Wawancara [1]

P : "Sekarang, coba jelaskan bagaimana langkah-langkah yang adik lakukan untuk menemukan jawaban terhadap masalah tersebut?"

P : "Dijelasin semuanya kak?"

S2: "Ya dek, langkah-langkahnya bagaimana?"

S2: "Awalnya saya melakukan pemisalan, kue kecil $=\mathrm{A}$ dan $\mathrm{kue}=\mathrm{B}$. Trus saya menghitung luas permukaan kedua kue tersebut karena permukaan kue itu bentuknya lingkaran maka saya menggunakan rumus $\pi \mathrm{r}^{2}$. Trus saya mencari luas, $3,14 \times 5^{2}=78,5 \mathrm{~cm}$. Lalu saya menghitung luas kue menjadi $3,14 \times 7,5^{2}=176,635 \mathrm{~cm}$. Jadinya luas kue kecil itu $3 \times 78,5=235,5 \mathrm{~cm}$ dan luas kue besar $2 \times 176,635=353,25 \mathrm{~cm}$. Berati membeli 2 kue besar lebih menguntungkan kak."

P : "Sebelumnya apa yang adik pahami dari masalah ini?"

S2: "Kita disuruh milih kak, apakah lebih untung itu membeli 2 kue besar atau 3 kue kecil kak."

P : "Trus bagaimana strategi yang adik gunakan untuk menjawab masalah ini?"

S2: "Saya menghitung dan membandingkan luas lingkaran dari kedua kue itu kak."

Berdasarkan jawaban dan hasil wawancara tersebut dapat diketahui bahwa pada tahap memahami masalah, S2 menguraikan informasi yang diketahui yaitu diameter kue kecil adalah $10 \mathrm{~cm}$ dengan harga Rp.10.000,00 dan diameter kue besar adalah $15 \mathrm{~cm}$ harga Rp. 15.000,00. Selain itu, S2 juga menjabarkan informasi yang ditanyakan, yakni "lebih untung beli tiga kue kecil atau 2 kue besar" pada jawabnnya. Hal ini membuktikan bahwa S2 telah melakukan dekomposisi dengan menyederhanakan masalah untuk memudahkan membangun penyelesaian.

Selanjutnya, S2 melakukan pemisalan pada tahap penyusunan strategi dengan menyatakan kue kecil $=\mathrm{A}$ dan kue besar $=\mathrm{B}$. Kemudian, S2 menghitung luas permukaan kedua kue tersebut menggunakan formula $\pi r^{2}$. Hal ini membuktikan bahwa S2 menemukan karateristik serupa dan menghubungkan masalah yang ada dengan materi yang sudah diperoleh yaitu luas lingkaran, sehingga dapat diklaim S2 melakukan pengenalan pola dalam memecahkan masalah tersebut.

Pada tahap melaksanakan rencana, S2 melakukan substitusi terhadap jari-jari kedua kue. S2 melakukan perhitungan dan ditemuka bahwa luas 3 kue kecil adalah 235,5 cm, sedangkan luas 2 kue besar adalah $353,25 \mathrm{~cm}$. Namun setelah menemukan luas permukaan total dari kedua kue tersebut S2 tidak membuat kesimpulan jawaban, sehingga dapat diklaim bahwa S2 belum mencapai indikator abstraksi. Selain itu, S2 juga belum mencapai tahap berpikir algoritma karena masih terdapat langkahlangkah yang tidak logis dan sistematis dalam memecahkan masalah tersebut

2. Proses Berpikir Komputasional S2 pada Pemecahan Masalah Matematika Saat Scaffolding

Berdasarkan Indikator berpikir komputasional, S2 hanya mampu mencapai tahap pengenalan pola. Maka peneliti melakukan scaffolding untuk merangsang tahapan berpikir komputasional S2 
secara optimal, sehingga dapat melakukan abstraksi dan berpikir algoritma. Berikut kutipan wawancara peneliti dengan S2 untuk memperbaiki proses berpikir komputasional S2 dalam memecahkan masalah matematika melalui scaffolding.

Wawancara [2]

P : "Setelah melihat jawaban adik, terlihat kalau adik sudah menentukan informasi yang diketahui dan informasi yang ditanyakan pada masalah tersebut. Kemudian menghitung luas permukaannya. Apakah benar?"

S2: "Nggih kak."

P : "Bagaimana adik mengetahui bahwa $r$ atau jari-jari kue kecil itu 5 dan jari-jari kue besar itu 7,5?" $\mathrm{S} 2$ : " $\mathrm{r}=1 / 2 \mathrm{~d}$ kak rumusnya."

$\mathrm{P}$ : "Oke, selanjutnya adik menghitung bahwa luas kue kecil atau kue $\mathrm{A}=235,5 \mathrm{~cm}$, sedangkan kue besar atau kue $\mathrm{B}=353,25 \mathrm{~cm}$, dan terdapat tanda ini maksudnya apa? (sambil menunjuk jawaban siswa)."

S2: "Maksudnya lebih untung membeli kue besar kak."

P : “Apa alasan adik mengatakan lebih untung membeli 2 kue besar?."

S2: "Karena setelah dihitung luas permukaan 2 kue besar itu lebih luas dari pada 3 kue kecil."

P : "Mmm kalau begitu apa kesimpulannya yang dapat diambil terkait solusi penyelesaian yang adik temukan?

S2: "Kesimpulannya adalah membeli 2 kue besar lebih menguntungkan dari pada 3 kue kecil karena 3 kue besar memiliki luas 353, $25 \mathrm{~cm}$, sementara 3 kue kecil 235,5 cm."

Berdasarkan kutipan wawancara [2], peneliti memberikan pertanyaan yang merangsang S2 untuk membuat kesimpulan terhadap solusi penyelesaian yang ditemukan. Melalui pertanyaan tersebut, terlihat S2 membuat kesimpulan bahwa lebih menguntungkan membeli 2 kue besar karena luas permukaannya lebih besar dari 3 kue kecil.

Selanjutnya, setelah kemampuan abstraksi S2 dapat dimunculkan, peneliti kembali memberikan scaffolding berupa pertanyaan yang merangsang siswa untuk berpikir secara algoritma yang dapat dilihat pada kutipan wawancara berikut.

Wawancara [3]

P : "Setelah kakak pertanyaan-pertanyaan tadi, sekarang sekarang apakah adik dapat menjelaskan bagaimana langkah-langkah untuk menemukan solusi penyelesaian terhadap masalah yang diberikan?".

S2: "Pertama menentukan yang diketahui dan ditanyakan, trus kita misalkan kue kecil itu A dan kue besar sebagai B. Trus dihitung luas permukaan kedua kue, sehingga nanti kita temukan bahwa membeli 2 kue besar lebih menguntungkan dari 3 kue kecil karena luas permukaanya kue besar lebih luas."

Berdasarkan kutipan wawancara [4], peneliti memberikan pertanyaan yang merangsang S2 menjabarkan langkah-langkah untuk menemukan solusi penyelesaian. Kemduian S2 memaparkan 
bagaimana langkah-langkah penyelesaian masalah dari awal hingga akhir. S2 menjelaskan apa yang diketahui pada masalah, apa yang ditanyakan masalah, dan bagaimana langkah-langkah untuk menemukan solusi dengan melakukan pemisalan, menghitung luas permukaan kedua kue, melakukan perbandingan terhadap luas permukaan kedua kue dan diakhiri kesimpulan jawaban.

Berikut jawaban siswa setelah diberikan scaffolding:

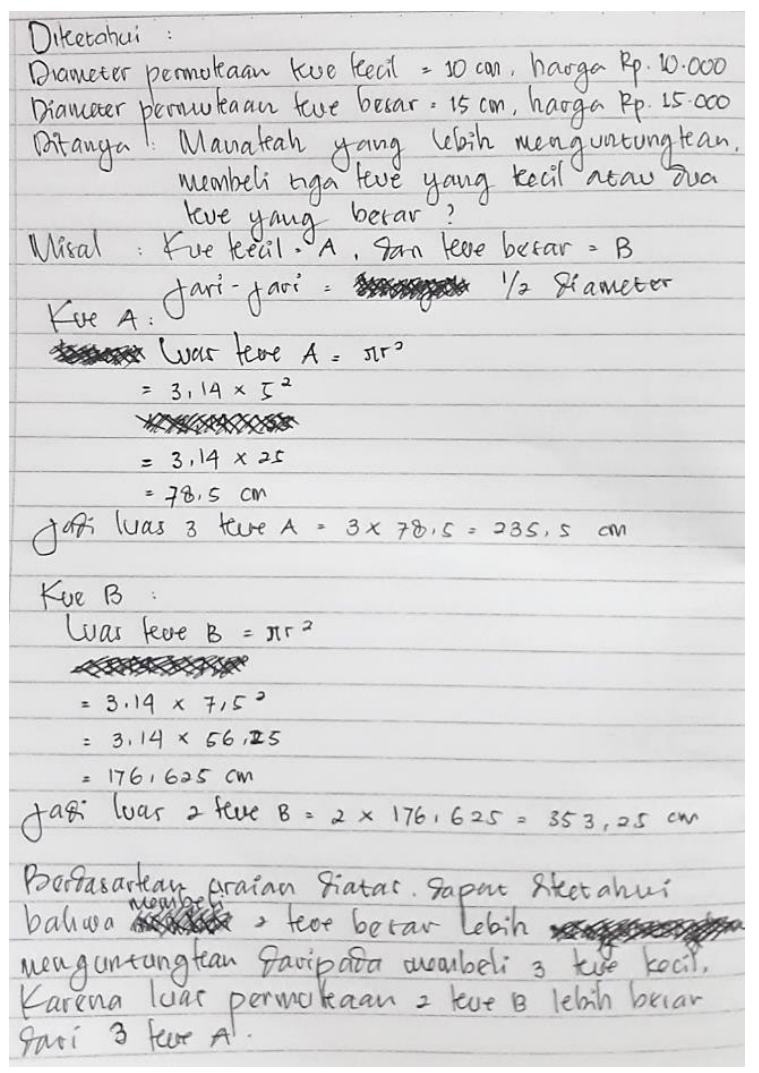

Gambar 5. Scaffolding S2

Berpikir komputasional sangat dibutuhkan untuk membantu dan memudahkan siswa dalam memecahkan masalah matematika. Kemampuan berpikir ini diperlukan karena melibatkan berbagai keahlian dan teknik yang melatih siswa merumuskan masalah dengan menjabarkan masalah tersebut menjadi bagian-bagian yang kecil yang mudah dipecahkan (Lee dkk., 2014). Hal ini terbukti dalam penelitian ini bahwa ketika siswa memecahkan masalah yang diberikan, langkah-langkah pemecahan masalah yang tidak lengkap dan tidak sistemas serta logis. Ketidaklengkapan langkah-langkah pemecahan masalah yang dimaksud seperti tidak menguraikan informasi yang diketahui dan ditanyakan, kesalahan dalam menghitung, dan tidak membuat kesimpulan dari solusi penyelesaian yang ditemukan terhadap masalah tersebut. Kesalahan-kesalahan inilah yang membuat siswa belum mampu mencapai tahap algoritma dalam berpikir komputasional.

Kesalahan-kesalahan yang dilakukan ternyata dapat diperbaiki dengan berbagai perlakuan, salah satunya melalui scaffolding. Scaffolding yang diberikan dapat membantu siswa dalam mengembangkan keterampilan berpikirnya dengan baik dalam pemecahan masalah matematika (Sunaryo \& Fatimah, 2019). Hal ini terbukti dengan pemberian scaffolding yang ternyata mendorong 
siswa mampu berpikir komputasional secara optimal ketika memecahkan masalah matematika, Selain itu, scaffolding yang diberikan tidak hanya berupa pertanyaan saja, tetapi juga berupa dorongan dan tuntunan hingga siswa dapat memecahkan masalah secara mandiri. Artinya, bantuan bisa berupa apa saja seperti pertanyaan, petunjuk, pengingat, arahan, atau dorongan yang diberikan kepada siswa saat melakukan kesalahan dalam menemukan solusi penyelesaian terhadap masalah yang ditemukan (Khatimah dkk., 2017; Maharani \& Subanji, 2018).

Scaffolding terbukti tidak hanya dapat membantu proses berpikir siswa secara umum, tetapi juga secara khusus seperti berpikir komputasional. Secara umum, scaffolding digunakan untuk memperbaiki struktur berpikir dan juga membantu siswa dalam memecahkan masalah matematika (Chairani, 2015). Meskipun begitu, pemberian scaffolding ternyata tidak hanya membantu, namun juga memperbaiki proses berpikir komputasional siswa atau kemampuan berpikir lainnya, seperti berpikir kritis (Kurniasih, 2012). Penelitian ini dan penelitian Kurniasih terkait scaffolding untuk berpikir kritis ternyata sejalan karena keduanya menunjukkan bahwa scaffolding juga dapat diberikan dan membantu meningkatkan kemampuan berpikir secara spesifik pada diri siswa.

\section{KESIMPULAN}

Berdasarkan hasil dan diskusi, scaffolding dapat membantu dan memperbaiki proses berpikir komputasional melalui pertanyaan, petunjuk, pengingat, arahan, atau dorongan yang diberikan hingga siswa mampu berpikir komputasional secara optimal ketika memecahkan masalah matematika. Hal ini dibuktikan dari tahapan berpikir komputasional siswa yang sebelumnya hanya mampu mencapai pengenalan pola menjadi siswa yang dapat mencapai tahap abstraksi dan berpikir algoritma dalam memecahkan masalah matematika.

Penelitian ini tentunya masih dapat diperdalam lagi dengan berbagai penelitian terkait seperti memperjelas jenis kesalahan yang dilakukan siswa melalui skema struktur berpikir dan proses defragmentasinya. Tak hanya itu, jenis scaffolding yang diberikan juga dapat diteliti lebih lanjut untuk mengetahui bentuk bantuan yang cocok untuk diberikan kepada siswa. Efektivitas scaffolding juga perlu dikaji kembali terhadap perbaikan kemampuan berpikir hingga defragmentasi struktur berpikir pada siswa.

\section{UCAPAN TERIMA KASIH}

Ucapan terima kasih kepada Prof. Dr. H. Turmudi, M. Si., Ph. D. selaku pembimbing dan penasihat dalam penyusunan artikel ini.

\section{REFERENSI}

Angeli, C., \& Giannakos, M. (2020). Computational thinking education: Issues and challenges. Computers in Human Behavior, 105.

Ayub, M., Wijanto, M. C., Senjaya, W. F., Karnalim, O., \& Kandaga, T. (2017). Edukasi Berpikir Komputasional melalui Pelatihan Guru dan Tantangan Bebras untuk Siswa di Bandung pada 
Pemberian Scaffolding untuk Memperbaiki Proses Berpikir Komputasional Siswa dalam Memecahkan Masalah

tahun 2016. Seminar Nasional Pengabdian Kepada Masyarakat, 2(2), 12-18.

Brackmann, C. P., Moreno-León, J., Román-González, M., Casali, A., Robles, G., \& Barone, D. (2017). Development of computational thinking skills through unplugged activities in primary school. ACM International Conference Proceeding Series, 65-72.

Chairani, Z. (2015). Scaffolding dalam pembelajaran matematika. Math Didactic: Jurnal Pendidikan Matematika, 1(1), 39-44.

Città, G., Gentile, M., Allegra, M., Arrigo, M., Conti, D., Ottaviano, S., Reale, F., \& Sciortino, M. (2019). The effects of mental rotation on computational thinking. Computers and Education, 141(June), 0-10.

Fatimah, S., Muhsetyo, G., \& Rahardjo, S. (2019). Proses Berpikir Tingkat Tinggi Siswa SMP dalam Menyelesaikan Soal PISA dan Scaffoldingnya. Jurnal Kajian Pembelajaran Matematika, 3(1), 24-33.

Harsa Wara Prabawa, \& H. R. S. M. (2019). Peningkatan Kemampuan Berpikir Komputasi Siswa Melalui Multimedia Interaktif Berbasis Model Quantum Teaching and Learning. International Journal of Computer Science Education in Schools, 8(1), 41.

Khatimah, K., Sa'dijah, C., \& Susanto, H. (2017). Pemberian Scaffolding untuk Mengatasi Hambatan Berpikir Siswa dalam Memecahkan Masalah Aljabar. Jurnal Kajian Pembelajaran Matematika, 1(April), 52-63.

Kurniasih, A. W. (2012). Scaffolding sebagai Alternatif Upaya Meningkatkan Kemampuan Berpikir Kritis Matematika. Kreano, Jurnal Matematika Kreatif-Inovatif, 3(2), 113-124.

Lee, T. Y., Mauriello, M. L., Ahn, J., \& Bederson, B. B. (2014). CTArcade: Computational Thinking with Games in School Age Children. International Journal of Child-Computer Interaction, 2(1), 26-33.

Maharani, I. P., \& Subanji, S. (2018). Scaffolding Based on Cognitive Conflict in Correcting the Students' Algebra Errors. International Electronic Journal of Mathematics Education, 13(2), $67-74$

Marcelino, M. J., Pessoa, T., Vieira, C., Salvador, T., \& Mendes, A. J. (2018). Learning Computational Thinking and scratch at distance. Computers in Human Behavior, 80, 470-477.

Nuraisa, D., Azizah, A. N., Nopitasari, D., \& Maharani, S. (2019). Exploring Students Computational Thinking based on Self-Regulated Learning in the Solution of Linear Program Problem. JIPM (Jurnal Ilmiah Pendidikan Matematika), 8(1), 30.

Pendidikan Matematika Realistik Indonesia (PMRI). (2011). Kontes Literasi Matematika (KLM). 126.

Selby, C. (2013). Computational Thinking: The Developing Definition. ITiCSE Conference 2013, 58.

Seymour Papert. (1980). Papert_Mindstorms.Pdf.

Sunaryo, Y., \& Fatimah, A. T. (2019). Pendekatan Kontekstual dengan Scaffolding untuk 
Meningkatkan Kemampuan Berpikir Kritis Matematis. JNPM (Jurnal Nasional Pendidikan Matematika), 3(1), 66.

Syah, A. I. R., \& Anistyasari, Y. (2020). Pengembangan Modul Pemrogaman Dasar untuk Meningkatkan Kemampuan Berpikir Komputasi. IT-Edu : Jurnal Information Technology and Education, 5(1), 1-6.

Tedre, M., \& Denning, P. J. (2016). The long quest for computational thinking. ACM International Conference Proceeding Series, 120-129.

Wing, J. (2014). Computational thinking benefits society. Journal of Computing Sciences in Colleges, 24(6), 6-7. 